Article

\title{
Acute Toxicity of Sodium Chloride, Nitrates, Ortho-Phosphates, Cadmium, Arsenic and Aluminum for Juveniles of the Freshwater Pearl Mussel: Margaritifera Margaritifera (L.1758)
}

\author{
Tiare Belamy *, Alexia Legeay, Bruno Etcheverria, Marie-Ange Cordier, Pierre-Yves Gourves and \\ Magalie Baudrimont \\ University Bordeaux, UMR EPOC CNRS 5805, F-33120 Arcachon, France; alexia.legeay@u-bordeaux.fr (A.L.); \\ bruno.etcheverria@u-bordeaux.fr (B.E.); marie-ange.cordier@u-bordeaux.fr (M.-A.C.); \\ pierre-yves.gourves@u-bordeaux.fr (P.-Y.G.); magalie.baudrimont@u-bordeaux.fr (M.B.) \\ * Correspondence: tiare.belamy@u-bordeaux.fr
}

Received: 30 April 2020; Accepted: 19 June 2020; Published: 23 June 2020

check for updates

\begin{abstract}
The freshwater pearl mussel (FWPM) Margaritifera margaritifera (L.1758) is critically endangered in Europe and ecotoxicological studies on the species are scares. Here, $96 \mathrm{~h}$ acute toxicity tests were conducted at $16{ }^{\circ} \mathrm{C}$ with sodium chloride $(\mathrm{NaCl})$, nitrates $\left(\mathrm{NO}_{3}{ }^{-}\right)$, ortho-phosphates $\left(\mathrm{PO}_{4}{ }^{3-}\right)$, cadmium (Cd), aluminum (Al) and arsenic (As) on 13- to 28-month-old post-parasitic juveniles. The experimental protocol was developed according to conditions described in a standard guide and was modified in order to assess toxicity thresholds for the Dronne River. Results showed that juveniles were tolerant to concentrations of $\mathrm{Al}, \mathrm{Cd}, \mathrm{As}, \mathrm{PO}_{4}{ }^{3-}, \mathrm{NO}_{3}{ }^{-}$and $\mathrm{NaCl}$, largely higher than those found in the Dronne river, since $96 \mathrm{~h}$ EC50s (effective concentrations) were $>954 \mu \mathrm{g} / \mathrm{L}$ for $\mathrm{Al} ;>110 \mu \mathrm{g} / \mathrm{L}$ for $\mathrm{Cd} ;>127 \mu \mathrm{g} / \mathrm{L}$ for As; $>5.01 \mathrm{mg} / \mathrm{L}$ for $\mathrm{PO}_{4}{ }^{3-}$; between 1000 and $1500 \mathrm{mg} / \mathrm{L}$ for $\mathrm{NO}_{3}{ }^{-}$ and were 1.19 and $1.33 \mathrm{~g} / \mathrm{L}$ for $\mathrm{NaCl}$. Moreover, the use of a substrate in experiments was found not to affect juvenile responses and younger juveniles seemed more sensitive than older individuals. This study thus provides new data about the tolerance of FWPM to environmental pollution and suggests that pollutant concentrations in the river are significantly lower than levels affecting them.
\end{abstract}

Keywords: juvenile freshwater pearl mussel; nutrients; metals; sensitivity; acute toxicity test

\section{Introduction}

Margaritifera margaritifera (L.1758) is among the most endangered freshwater species in Europe [1]. The population of this freshwater pearl mussel (FWPM) has been declining since the 20th century due to pearl fishing, an alteration in water quality, habitat degradation, decline of host fish and pollution [2-8]. In Europe, several programs have been set up in order to preserve this species by restoring habitats and by the application of captive breeding techniques for the reintroduction of M. margaritifera into its natural habitats [9]. But the knowledge of the best ecological and ecotoxicological requirements for the survival of this species in the field is still mostly lacking. Margaritifera margaritifera (L.1758) is a long-lived species presenting a complex life cycle that includes a compulsory parasitic stage during which the larvae (also called glochidium) must attach to the gills of a suitable fish host in order to allow glochidium metamorphosis into juvenile stage $[10,11]$. The juvenile stage starts when metamorphosed glochidia fall from the gills of the fish to settle on the river bottom, until they reach sexual maturity after 10 to 15 years [3]. Otherwise, post-parasitic juveniles (also called freshly excysted juveniles) are suggested to be the most critical stage of the FWPM [12,13]. Since the first developmental stages of freshwater mussels are often more vulnerable than the adult stage [14-16], extensive investigation 
into assessing the sensitivity of the early life stages of the FWPM is, therefore, highly relevant for ecotoxicological study and in helping to find the best conservation strategies for this endangered species $[5,15,17]$.

Research on some ecological requirements of the FWPM are well documented, including reports on its feeding requirements, laboratory holding conditions and species ontogeny [18-22]. With its general tendency to cause habitat degradation or alteration in water quality, pollution appears to be an important factor in the declining population of the FWPM [1,23,24]. Nutrient input to rivers from various anthropogenic sources, such as municipal and industrial sewage effluents and agricultural runoff, contributes to increased nutrient concentrations in freshwater ecosystems [24-26]. Elevated nutrient concentrations leading to the eutrophication process can adversely affect organisms [26,27] and notably the FWPM since this species inhabits oligotrophic rivers [28]. Thus, it is necessary to directly assess the effects of such contaminants on the FWPM. Field observations have allowed the estimation of water-quality thresholds in terms of population size, recruitment and distribution within rivers, with very low values especially for nutrients involved in water eutrophication such as nitrate $\left(\mathrm{NO}_{3}{ }^{-}\right)$and ortho-phosphate $\left(\mathrm{PO}_{4}{ }^{3-}\right)[23,29,30]$. An Irish study first estimated minimal Margaritifera water-quality standards for those two nutrients: $7.5 \mathrm{mg} / \mathrm{L}$ for $\mathrm{NO}_{3}{ }^{-}$and $0.06 \mathrm{mg} / \mathrm{L}$ for $\mathrm{PO}_{4}{ }^{3-}$ [29]. Subsequently in 2006, the same author [30] assessed median river levels at which Margaritifera is capable of reproduction and estimated lower values of $0.553 \mathrm{mg} \mathrm{NO}_{3}{ }^{-} / \mathrm{L}$ and $0.005 \mathrm{mg} \mathrm{PO}_{4}{ }^{3-} / \mathrm{L}$ for nitrate and ortho-phosphate, respectively. This finding thus addresses the need to study the toxicity effect of both nutrients on the FWPM since these values are considerably lower than concentrations found in the field. Moreover, these values are also lower than the European drinking-water threshold standard for nitrate: $50 \mathrm{mg}$ $\mathrm{NO}_{3}{ }^{-} / \mathrm{L}$ and lower than $1 \mathrm{mg} \mathrm{PO}_{4}{ }^{3-} / \mathrm{L}$ for ortho-phosphates, which represent the threshold values between net and significant water pollution in terms of water quality [31].

As filtering and sediment living organisms, the FWPM is inevitably exposed to the potential presence of contaminants, since surface water and sediments are important routes of exposure for these bivalves [32]. Metal trace elements (MTE) that enter into aquatic ecosystems are absorbed by suspended particles that subsequently accumulated in the sediment. MTE are known to exert harmful effects on freshwater bivalves by causing mortality, alterations in weight, changes in enzyme activity, filtration rate and behavioral modifications [14,33-38]. In particular, cadmium (Cd) is well known to impact on bivalve mollusks, notably $M$. margaritifera from the Dronne river in the Dordogne region of France $[39,40]$. Moreover, arsenic (As) and aluminum (Al) were found to be present in the upper part of this river, especially in the sediment, from to studies developed in the European Financial Instrument for the Environment (LIFE) Project (LIFE 13 NAT/FR/000506) which aims to preserve the largest French population of M. margaritifera contained in the Dronne river. This project also allowed the development of a rearing facility in 2016 in Firbeix (France), in order to produce the FWPM, a subpopulation of which is reintroduced in the Dronne river after one or two years of culture, while the remainder are used for ecotoxicological studies. Currently, the total population of M. margaritifera in France has been estimated at 100,000 individuals dispersed in 82 different rivers [41], with the Dronne river accounting for $15 \%$ of this population, making ecotoxicological studies on this river of major interest in preserving this species.

The aim of this study was first to develop a suitable experimental protocol for testing FWPM juveniles in toxicology studies focused on the toxicity threshold determination for the Dronne river. Indeed, experimental conditions were selected in order to get closer to the conditions found in this river, by using a substrate sand, the Dronne river water as dilution water and juveniles aged more than one year old (corresponding to the age of juveniles that are reintroduced in the Dronne river), in our experiments. The objective was then to assess toxicity thresholds for sodium chloride $(\mathrm{NaCl})$, nitrates $\left(\mathrm{NO}_{3}{ }^{-}\right)$, ortho-phosphates $\left(\mathrm{PO}_{4}{ }^{3-}\right), \mathrm{Cd}$, As and $\mathrm{Al}$ on artificially reared juveniles of the FWPM and to compare, when possible, their sensitivity according to age, in experiments conducted on animals from the same cohort at different times during the year. The contaminants As and Al were chosen according to their concentrations found in the Dronne river study site, whereas Cd was employed 
for a comparative assessment of its effects on juvenile versus adult $M$. margaritifera. The selected nutrients were studied to provide new data and add to the current literature on the general effects of nutrients on freshwater bivalves. Our results are expected to assess contaminant levels that could affect FWPM juveniles and, therefore, improve our knowledge about the pollutant sensitivity of this endangered species.

\section{Materials and Methods}

\subsection{Test Organisms and Laboratory Culture Conditions}

Juvenile mussels (M. margaritifera) were produced in vivo using the brown trout (Salmo trutta) as the fish host at the Firbeix captive rearing facility situated near the Dronne river (France). After juvenile mussels were excysted from their fish hosts, they were housed at the rearing facility in a flow-through system using $160 \mathrm{~L}$ tanks containing silicate sand as a substrate. The animals were kept in the farm facility for one to two years before reintroduction into the natural environment or are used for research experiments. For our experiments, organisms were transported to the laboratory of the marine station of Arcachon (France) about $250 \mathrm{~km}$ away from the facility farm, in a cool box with frozen gel packs ensuring a temperature of about $12{ }^{\circ} \mathrm{C}$. They were then transferred to a $300 \mathrm{~mL}$ plastic box without substrate and filled with aerated Dronne river water. The viability of juveniles was checked before and after the shipment. Once in the laboratory, the plastic boxes containing juveniles were placed in a $16{ }^{\circ} \mathrm{C}$ water bath in order to raise the temperature and ensure organism acclimatization. After that, the juveniles were kept in a closed recirculating system consisting of $50 \mathrm{~L}$ glass aquaria placed in a $16^{\circ} \mathrm{C}$ water bath and filled with Dronne river water. The aquaria water was continuously filtered through a pump and inflow to the aquaria was via a spray bar allowing water aeration. Within these aquaria, individuals were placed in $100 \mathrm{~mL}$ experimental units (width $120 \mathrm{~mm}$, height $30 \mathrm{~mm}$ ) filled with a silicate sand substrate (diam. 0.8-1.4 mm obtained from Sibelco, Mios, France). Juveniles were fed daily with a mixture of living freshwater algae (Scenedesmus subspicatus, Chlorella vulgaris and Stichococcus bacillaris) cultivated in the laboratory. Half of the culture water volume was renewed twice monthly. Water physico-chemistry was based on averages from October 2017 to January 2018: Temperature $16.5^{\circ} \mathrm{C}$ (range 16.3-16.7); dissolved oxygen $8.50 \mathrm{mg} / \mathrm{L}$ (range 7.24-9.60); $\mathrm{pH} 7.48$ (range 7.10-7.80); conductivity $84.25 \mu \mathrm{S} / \mathrm{cm}$ (range 72.8-93.8). This culture system was tested over 4 months to ensure organisms viability at the laboratory. Dronne river water, used for dilution purposes in experiments and culture water for maintaining the mussels, was collected at the rearing facility and stored at $4{ }^{\circ} \mathrm{C}$ at the laboratory. All organisms used in these experiments originated from the same cohort produced in 2016. FWPM larvae, also called glochidia, were collected from the Dronne river in August 2016 allowing juveniles production in December 2016. In this study, the age of juveniles is expressed as the number of months after the point of dropping from the gills of the host fish.

\subsection{Acute Toxicity Testing}

Initial experiments were conducted in order to assess the effective concentrations (EC50) and (EC10) corresponding respectively to the concentration of contaminant that affected $50 \%$ and $10 \%$ of the population studied, respectively. We conducted $96 \mathrm{~h}$ acute toxicity tests according to the standard guide for conducting laboratory toxicity testing with freshwater mussels (American Society for Testing Material E2455 2006) [42], but with some modifications. Each test comprised four replicates for each of five exposure concentrations, along with a control condition. Tests were conducted in $300 \mathrm{~mL}$ glass beakers containing $150 \mathrm{~mL}$ of test solution. Unlike the recommendation of ASTM E2455 2006 [42], silicate sand was used as the substrate in order to allow mussels to burrow during the test period which we considered to more relevant for sediment dwelling species and Dronne river water was used for dilution water in experiments. We employed the same artificial substrate (diam. 0.8-1.4 mm obtained from Sibelco, Mios, France) used for M. margaritifera's production at the Firbeix farm facility since the typical substrate preference for the FWPM are small sand patches stabilized amongst large 
stones or boulders [28]. Each experimental unit contained about $1 \mathrm{~cm}$ thickness of substrate. Before the start of a given test, juvenile viability was verified under a binocular microscope by observing foot movement during a $5 \mathrm{~min}$ trial. Individuals showing no movement within this period were recorded as impacted juveniles and were discarded. Live mussels were randomly placed in each beaker to a number of 5 (corresponding to 20 juveniles per exposure condition). The experimental units were continuously aerated and placed in a water bath at $16^{\circ} \mathrm{C}$, corresponding to the holding temperature at the rearing facility, which was closed to the mean temperature $\left(14^{\circ} \mathrm{C}\right)$ of the Dronne river throughout 2016. Water physico-chemistry $\left(\mathrm{T}^{\circ} \mathrm{C}, \mathrm{pH}\right.$, conductivity and dissolved oxygen) was measured at the beginning $(0 \mathrm{~h})$ and at the end $(96 \mathrm{~h})$ of each experimental test with control, low-, medium- and high-contaminant concentrations. The viability of juveniles was again assessed at 48 and $96 \mathrm{~h}$. In order to validate our method of exposure and to validate the use of a substrate, experiments with or without the use of substrate were conducted following the same experimental protocol as described above with $\mathrm{NaCl}$ as a reference toxicant $[43,44]$ and $\mathrm{Cd}$. Given that the juveniles in this study came from the same cohort, experiments were conducted at different times between 2017 and 2018, allowing data comparisons to be made between animal groups of the same cohort in function of juveniles age. Organisms used for toxicity tests ranged in age from 13 to 28 months post-parasitic stage and toxicity tests were not conducted on newly transformed juveniles since new pearl mussel were produced the next year. However, in the context of the Dronne river, studies on older juveniles were more relevant since juveniles are reintroduced in the natural field after one or two years of culture at the rearing facility. Tests were carried out with static water without renewal and the animals were unfed for the duration of experiments. The test acceptability criterion was control survival $>90 \%$ according to the ASTM E2455 2006 [42].

\subsection{Water Physico-Chemistry and Chemical Analysis}

Toxicants used were as follows: reagent-grade salts dissolved in de-ionized water for sodium chloride ( $\mathrm{NaCl}$, reagent grade; USB Corporation, Cleveland, $\mathrm{OH}, \mathrm{USA})$, nitrate $\left(\mathrm{NO}_{3}{ }^{-}\right)$as sodium nitrate $\left(\mathrm{NaNO}_{3}, 99.5 \%\right.$ purity; Prolabo, Paris, France) and ortho-phosphates $\left(\mathrm{PO}_{4}{ }^{3-}\right)$ as sodium phosphate dibasic $\left(\mathrm{Na}_{2} \mathrm{HPO}_{4}, 99 \%\right.$ purity; Sigma Aldrich, St. Louis, MO, USA). Metal solutions were obtained from Merck with cadmium as $\mathrm{CdCl}_{2}$, arsenic as $\mathrm{As}_{2} \mathrm{O}_{5}$ and aluminum as $\mathrm{AlCl}_{3}$ all in $\mathrm{H}_{2} \mathrm{O}$. For metal concentration determinations, water samples were acidified at $10 \%$ with $65 \%$ nitric acid $\left(\mathrm{HNO}_{3}\right.$, Merck, Kenilworth, NJ, USA) directly after each sample collection. Cadmium and arsenic exposure concentrations were measured by Atomic Adsorption Spectrometry (SAA 240Z Agilent, Santa Clara County, CA, USA) and aluminum exposure concentrations were measured by inductively coupled plasma optical spectrometry (ICP-OES, 700 series, Agilent). The detection limits were $0.075 \mu \mathrm{g} / \mathrm{L}$ and $0.5 \mu \mathrm{g} / \mathrm{L}$ for cadmium and arsenic, respectively. Because of its high adsorption properties, cadmium concentration was measured in the testing solutions after $24 \mathrm{~h}$ during the acute $96 \mathrm{~h}$ toxicity tests and readjusted as necessary. Nutrients as nitrates and phosphates, were measured by gas-segmented continuous flow analysers (SFA) for the determination of dissolved nutrients (AA3-HR, SEAL ANALYTICAL) for phosphates and QuAAtro (QuAAtro, SEAL ANALYTICAL) for nitrates. The quantification limits were $0.21 \mu \mathrm{M} / \mathrm{L}(0.013 \mathrm{mg} / \mathrm{L})$ and $0.005 \mu \mathrm{M} / \mathrm{L}(0.002 \mathrm{mg} / \mathrm{L})$ for nitrates and phosphates, respectively. Water physico-chemistry was checked as recommended by ASTM E2455 2006 [42], at the beginning and at the end of each test using measuring cells (WTW, Germany): Profiline Oxi 3205 for dissolved oxygen, Profiline $\mathrm{pH} 3110$ for $\mathrm{pH}$ and Profiline Cond 3110 for temperature and conductivity. Nominal concentrations tested were as follows: $0,5,15,30,60$ and $120 \mu \mathrm{g} / \mathrm{L}$ for As and $\mathrm{Cd} ; 0,120,250,500,750$ and $1000 \mu \mathrm{g} / \mathrm{L}$ for Al; 0, 0.2, 0.6, 1.6, 3, $6 \mathrm{mg} / \mathrm{L}$ for $\mathrm{PO}_{4}{ }^{3-} ; 0,128,256,512$, 1024 and $2048 \mathrm{mg} / \mathrm{L}$ for $\mathrm{NO}_{3}{ }^{-}$and $0,0.2,0.4,0.8,1.2$ and $1.6 \mathrm{~g} / \mathrm{L}$ for NaCl . As and Al concentrations were chosen according to their maximum concentrations found in the Dronne river, which were about $35 \mu \mathrm{g} \mathrm{As} / \mathrm{L}$ in 2015 and $120 \mu \mathrm{g} \mathrm{Al} / \mathrm{L}$ in 2018. Concentrations tested for As and Cd were the same in order to compare the effect of both metals, although the Cd concentration measured in the Dronne river was under the detection limit in 2015 and $2018(<0.61 \mu \mathrm{g} / \mathrm{L})$. Nitrates concentrations were first 
chosen according to thresholds found in the literature [30], with the highest concentration tested being $8 \mathrm{mg} \mathrm{NO}{ }_{3}^{-} / \mathrm{L}$. However, at the end of the testing under such $\mathrm{NO}_{3}{ }^{-}$conditions, viability was found to be $100 \%$. Therefore, in order to assess the median effective concentration, the experiment was conducted again with higher concentrations that were chosen according to nitrates median effective concentrations found in the literature for other species of freshwater mussels from the Unionidae family [25].

\subsection{Data Analysis}

Statistical analyses were performed using RStudio version 1.1.442. Normality and homoscedasticity were checked using the Levene test. Differences in age-related sensitivity or between the presence or absence of a substrate, were assessed by parametric testing with a two-way analysis of variance (ANOVA) with post-hoc Tukey analysis, or when necessary, by a non-parametric test using Kruskall-Wallis with a post hoc Dunn test. Values were first converted from percentages to arcsin functions for survival data. Effective concentrations (EC50) and (EC10) values were calculated from nominal concentrations for sodium chloride and from measured concentrations for all other toxicants. These toxicity thresholds were assessed with a three parameters log-logistic model allowing us to obtain where possible, the EC50 and the EC10 with corresponding to 95\% confidence intervals [45].

\section{Results}

\subsection{Validation of the Protocol}

Acute toxicity tests were carried out in order to assess median effective concentrations of $\mathrm{NaCl}$, $\mathrm{NO}_{3}{ }^{-}, \mathrm{PO}_{4}{ }^{3-}, \mathrm{Cd}, \mathrm{As}$ and $\mathrm{Al}$ for several month-old juveniles of $M$. margaritifera. The tests were conducted according to ASTM E2455 2006 guidelines [42], but with some modifications. Whereas this standard recommendation is based on water-only exposure, in the present study, silicate sand was employed to provide a substrate that more closely resembles the natural environment of the burrowing FWPM. In order to validate the use of a silicate sand substrate, acute toxicity tests in the substrate's presence or absence were conducted simultaneously on 22-month-old juveniles under $\mathrm{NaCl}$ and Cd exposure. Survival control was $100 \%$ at the end of the $96 \mathrm{~h}$ acute toxicity test for all conditions (Supplementary data, Table S3). The EC50s for $\mathrm{NaCl}$ in tests conducted with and without the sand substrate were $1.33 \pm 0.09 \mathrm{~g} \mathrm{NaCl} / \mathrm{L}$ and $1.19 \pm 0.08 \mathrm{~g} \mathrm{NaCl} / \mathrm{L}$ respectively (Figure 1 ). Statistical analyses showed no differences in the percentage of juvenile viability at each exposure concentrations of $\mathrm{NaCl}$ in tests conducted with or without a substrate $(p>0.05)$.

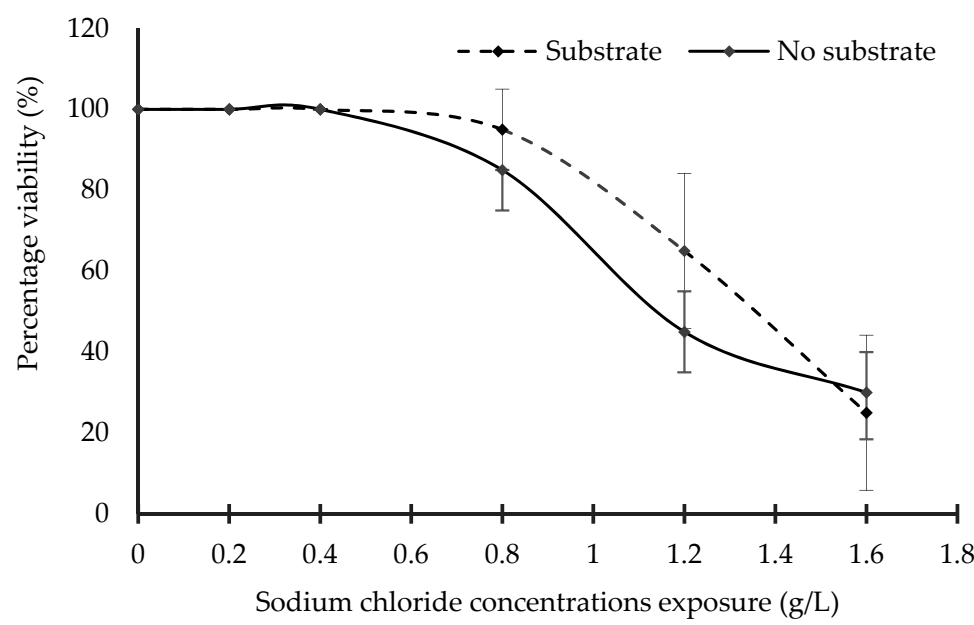

Figure 1. Viability ( $\% \pm$ standard deviation (SD)) of 22-month-old M. margaritifera juveniles exposed to sodium chloride in $96 \mathrm{~h}$ acute toxicity tests conducted with substrate (dashed line) or without (solid line) a sand substrate at $16^{\circ} \mathrm{C}$. 
Under exposure to $\mathrm{Cd}$, viability was $100 \%$ for all concentrations and both substrate (with or without) conditions at the end of the $96 \mathrm{~h}$ experiments. The high variability found in cadmium measured concentration measurements is due to the adjustment after $48 \mathrm{~h}$ of exposure by the compensated additions method, allowing mean cadmium concentrations to be maintained constant throughout each experiment (Supplementary data, Table S3). Nevertheless, comparison of Cd exposure concentrations showed no differences between the two tests for each exposure concentration $(p>0.05)$ (Supplementary data, Table S3). Measured physico-chemical parameters (temperature, $\mathrm{pH}$, dissolved oxygen and conductivity) during $\mathrm{Cd}$ and $\mathrm{NaCl}$ acute toxicity tests were remained very similar in the two substrate conditions (Supplementary data, Table S2).

\subsection{Toxicity Thresholds}

Table 1 summarizes the median effective concentrations (EC50) obtained in $96 \mathrm{~h}$ acute toxicity tests for $\mathrm{NaCl}, \mathrm{Al}, \mathrm{As}, \mathrm{Cd}, \mathrm{NO}_{3}{ }^{-}$and $\mathrm{PO}_{4}{ }^{3-}$. The values obtained with or without the use of a substrate in these experiments and the total number of organisms used for each test are also presented. Overall, in the acute toxicity tests conducted, only a few EC50s could be established. Indeed, a 50\% population effect rate was not reached for the highest exposure concentrations tested for $\mathrm{Al}, \mathrm{As}, \mathrm{Cd}$ and $\mathrm{PO}_{4}{ }^{3-}$. The $96 \mathrm{~h}$ acute toxicity thresholds were higher than $954 \mu \mathrm{g} / \mathrm{L}$ for aluminum; over 110 , 112 and $147 \mu \mathrm{g} / \mathrm{L}$ for cadmium toxicity tests; higher than $127 \mu \mathrm{g} / \mathrm{L}$ for arsenic, and over $5.01 \mathrm{mg} / \mathrm{L}$ for phosphates. Moreover, in the nitrate exposure test, we were unable to assess the exact median effective concentration because the dilution factor between two exposure concentrations was too high. In fact, the percentage viability at the end of the test to medium-high concentration exposure was $80 \%$, whereas all organisms died in the highest exposure condition. However, the data allowed us to determine a range of toxicity threshold values between 1000 to $1500 \mathrm{mg} \mathrm{NO}_{3}{ }^{-} / \mathrm{L}$, which is not representative of the natural environmental conditions. EC10s were assessed for the two $\mathrm{NaCl}$ toxicity tests and for the cadmium acute toxicity test conducted on 16-month-old juveniles. These values were as follow with corresponding confident intervals: $0.64(0.53-0.77) \mathrm{g} \mathrm{NaCl} / \mathrm{L}$ for the $96 \mathrm{~h}$ toxicity test conducted without substrate; $0.91(0.75-1.08) \mathrm{g} \mathrm{NaCl} / \mathrm{L}$ for the $96 \mathrm{~h}$ toxicity test conducted with substrate, and 75 (55-95) $\mu \mathrm{g} \mathrm{Cd/L}$. The EC10 for nitrate could not be established for the same reason as our inability to determine the exact EC50. Similarly, the EC10s could not be calculated for all the other contaminants since survival was $100 \%$ at the end of the trials for the highest concentrations tested. Mean measured values of water-quality parameters $(\mathrm{pH}$, conductivity, dissolved oxygen and temperature) for all acute toxicity tests presented in Table 1 were measured at the beginning and at the end of the test (See Supplementary data, Table S2). Nominal and mean measured concentration of toxicants, and juveniles' viability at the end of the tests are presented as Supplementary data, Table S3. 
Table 1. Median effective concentrations (EC50s) in $96 \mathrm{~h}$ acute toxicity tests with sodium chloride, nitrates, phosphates, cadmium and arsenic for M. margaritifera juveniles. $\left(\mathrm{T}^{\circ} \mathrm{C}=16{ }^{\circ} \mathrm{C}\right)(n=4)$.

\begin{tabular}{|c|c|c|c|c|c|c|c|}
\hline \multicolumn{2}{|c|}{ Toxicants or Nutrients } & \multirow{2}{*}{$\begin{array}{c}\begin{array}{c}\text { Age of Organisms } \\
\text { (Months) }\end{array} \\
22\end{array}$} & \multirow{2}{*}{$\begin{array}{c}\text { Substrate } \\
\text { No }\end{array}$} & \multirow{2}{*}{$\begin{array}{c}\text { Total Number of } \\
\text { Organisms }\end{array}$} & \multirow{2}{*}{$\begin{array}{c}\text { EC50 (48 h) } \\
>1.6^{1}\end{array}$} & \multirow{2}{*}{$\begin{array}{c}\text { EC50 (96 h) } \\
1.19(1.11-1.28)\end{array}$} & \multirow{2}{*}{$\begin{array}{l}\text { Units } \\
\mathrm{g} / \mathrm{L}\end{array}$} \\
\hline $\mathrm{NaCl}$ & Sodium Chloride & & & & & & \\
\hline $\mathrm{NaCl}$ & Sodium Chloride & 22 & Yes & 120 & $1.5(1.35-1.66)$ & $1.33(1.24-1.42)$ & $\mathrm{g} / \mathrm{L}$ \\
\hline $\mathrm{NO}_{3}^{-}$ & Nitrates & 13 & Yes & 120 & $>2290^{1}$ & $1000-1500^{2}$ & $\mathrm{mg} / \mathrm{L}$ \\
\hline $\mathrm{PO}_{4}^{3-}$ & Phosphates & 13 & Yes & 120 & $>5.01^{1}$ & $>5.01^{1}$ & $\mathrm{mg} / \mathrm{L}$ \\
\hline $\mathrm{CdCl}_{2}$ & Cadmium & 16 & Yes & 120 & $>112^{1}$ & $>112^{1}$ & $\mu \mathrm{g} / \mathrm{L}$ \\
\hline $\mathrm{CdCl}_{2}$ & Cadmium & 22 & No & 120 & $>147^{1}$ & $>147^{1}$ & $\mu \mathrm{g} / \mathrm{L}$ \\
\hline $\mathrm{CdCl}_{2}$ & Cadmium & 22 & Yes & 120 & $>110^{1}$ & $>110^{1}$ & $\mu \mathrm{g} / \mathrm{L}$ \\
\hline $\mathrm{As}_{2} \mathrm{O}_{5}$ & Arsenic & 17 & Yes & 96 & $>127^{1}$ & $>127^{1}$ & $\mu \mathrm{g} / \mathrm{L}$ \\
\hline $\mathrm{AlCl}_{3}$ & Aluminum & 28 & Yes & 120 & $>954^{1}$ & $>954^{1}$ & $\mu \mathrm{g} / \mathrm{L}$ \\
\hline
\end{tabular}

Numbers in parentheses denote 95\% confidence intervals; ${ }^{1}$ Insufficient effect on mobility for assessing EC50; ${ }^{2}$ Range values of EC50 where the dilution factor between exposure concentrations was too high 


\subsection{Age-Related Sensitivity}

Table 2 shows the mean survival of juveniles in $96 \mathrm{~h}$ acute toxicity tests to $\mathrm{Cd}$ for 16 - and 22-month old juveniles. The viability of 16-month-old juveniles was affected at $120 \mu \mathrm{g} \mathrm{Cd} / \mathrm{L}$ with $80 \%$ survival occurring, while the viability of 22-month-old juveniles was not affected even at the highest exposure concentration. For $\mathrm{NaCl}$ exposure conducted with sediment, the 48-h EC50 assessed for 22-month-old juveniles was $1.5 \mathrm{~g} \mathrm{NaCl} / \mathrm{L}$ with a $95 \%$ confidence interval of between 1.35 and 1.66. A previous experiment conducted on 10-month-old juveniles allowed to assess 48 -h EC50 of $0.96 \mathrm{~g} \mathrm{NaCl} / \mathrm{L}$ with a 95\% confidence interval of between 0.88 and 1.05 (Supplementary data, Figure S1, Table S1). However, missing data of this experiment such as water-quality parameters at the end of the experiment or measured $\mathrm{NaCl}$ concentrations, and the short duration of the acute toxicity test ( $48 \mathrm{~h}$ ) did not allow us to confirm the robustness of these results but provided interesting information concerning the sensitivity of the youngest juveniles studied in this present study. Indeed, the EC50 seems to be 0.5-fold lower than for 22-month-old juveniles (1.5 (1.35-1.66) $\mathrm{g} \mathrm{NaCl} / \mathrm{L})$. Moreover, in terms of mean survival, the viability of 10 -month-old juveniles was affected at $1 \mathrm{~g} \mathrm{NaCl} / \mathrm{L}$ with $45 \%$ of organisms remaining alive (Supplementary data, Figure S1), whereas 70\% of 22-month-old juveniles were still alive after $1.2 \mathrm{~g} \mathrm{NaCl} / \mathrm{L}$ exposure (Supplementary data, Table S3).

Table 2. Mean survival (\%) and median effective concentrations for cadmium ( $\mu \mathrm{g} \mathrm{Cd} / \mathrm{L}$ ) in acute toxicity tests with a substrate for 16- and 22-month-old $M$. margaritifera juveniles, $\mathrm{T}^{\circ} \mathrm{C}=16{ }^{\circ} \mathrm{C}$.

\begin{tabular}{ccc}
\hline \multirow{2}{*}{$\mathbf{n}(\mu \mathrm{g} / \mathrm{L})^{\mathbf{1}}$} & \multicolumn{2}{c}{ Organisms Age } \\
\cline { 2 - 3 } & $\mathbf{1 6}$ Months & 22 Months \\
\hline Control & 100 & 100 \\
5 & 100 & 100 \\
15 & 100 & 100 \\
30 & 100 & 100 \\
60 & 95 & 100 \\
120 & 80 & 100 \\
\hline${ }^{1}$ Expressed as nominal concentrations; ${ }^{2}$ Expressed as measured concentrations.
\end{tabular}

\section{Discussion}

\subsection{Experimental Procedure}

The lack of knowledge about the endangered FWPM's sensitivity to pollutants and the scarcity of laboratory testing on this species, due mostly to its complex life cycle, provided the initial impetus to develop suitable experimental protocols for investigating this organism's ecotoxicology. Although the protocols we employed complied mostly with ASTM E2455 2006 [42] guidelines, some important modifications were introduced such as a substrate, the use of Dronne river water as the dilution water, and the use of juveniles aged of more than one year. Our results showed that the presence of silicate sand as a substrate in $96 \mathrm{~h}$ acute toxicity tests did not impact either on water quality parameters or toxicant concentrations, and did not affect the juveniles' sensitivity, since EC50s in $\mathrm{NaCl}$ toxicity tests conducted with a substrate and without any, were similar with overlapping confidence interval (1.33 (1.24-1.42) $\mathrm{g} \mathrm{NaCl} / \mathrm{L}$ and 1.19 (1.11-1.28) $\mathrm{g} \mathrm{NaCl} / \mathrm{L}$, respectively), thus validating our method of exposure. However, these results also showed that in acute toxicity tests, the presence of a substrate is not necessary, as recommended by the ASTM E2455 2006 [42], but with respect to this present study objectives, the use of a substrate in our experiments met conditions that corresponded more closely to this burrowing mussel's natural environment, notably in the Dronne river. A previous study on the unionid mussel (Lampsilis siliquoidea) in 28-day chronic toxicity tests to ammonia, conducted with soil substrate ranging in size of 300 to $500 \mu \mathrm{m}$ and conducted without any, similarly found that the presence of a substrate did not influence the toxicant sensitivity of this freshwater mussel [46]. 
However, the same author conducted more recently another study based on the same experimental test on chronic toxicity to $\mathrm{NaCl}$ and potassium chloride $(\mathrm{KCl})$ with silica sand (particle size of 100 to $400 \mu \mathrm{m}$ ) used as substrate and reported that EC20, based on biomass endpoint, in substrate presence, was twofold lower than without substrate [47]. This indicates that the mussel responses in the presence or absence of substrate might be dependent on the exposure duration and might differ according to the endpoint studied. Nevertheless, in this present study, acute toxicity tests were conducted for $96 \mathrm{~h}$ and the endpoint was juvenile's immobility. In order to further validate the experimental protocol developed in the present study, acute toxicity tests were conducted using $\mathrm{NaCl}$ as a reference toxicant, which is amongst those toxicants used to assess the health and sensitivity of organisms generally, thereby allowing a comparison over time to be made between organisms of different species [43,44]. FWPM juveniles displayed a dose-dependent sensitivity to sodium chloride: the median effective concentration for 22-month-old juveniles in $96 \mathrm{~h}$ acute toxicity tests were 1.33 (1.24-1.42) g NaCl/L and $1.19(1.11-1.28) \mathrm{g} \mathrm{NaCl} / \mathrm{L}$ in the presence or absence of substrate, respectively. Moreover, the EC10s were $0.64(0.53-0.77) \mathrm{g} \mathrm{NaCl} / \mathrm{L}$ and 0.91 (0.75-1.08) $\mathrm{g} \mathrm{NaCl} / \mathrm{L}$ in $96 \mathrm{~h}$ tests conducted with and without a substrate, respectively. An earlier study in which the $96 \mathrm{~h}$ median effective concentrations for chloride (tested as sodium chloride) on 6- to 10-day-old post-parasitic juveniles of five other species of freshwater mussels (four from the family Unionidae and one from the family Margaritiferidae) were established, reported EC50s values ranging from 1.038 to $2.246 \mathrm{~g} \mathrm{Cl} / \mathrm{L}$ (1.711 to $3.703 \mathrm{~g} \mathrm{NaCl} / \mathrm{L})$ [48]. However, it has been shown that water chemistry as water hardness, was impacting sensitivity to $\mathrm{NaCl}$ toxicity for mussels [49] and for other freshwater organisms [50-52], with increasing water hardness leading to decreasing sensitivity to $\mathrm{NaCl}$. In this present study, water hardness was not measured which makes it difficult to compare the sensitivity of $M$. margaritifera juveniles to $\mathrm{NaCl}$ with mussel juveniles of the previous study [48]. Although median effective concentrations obtained in our study were assessed on 22-month-old juveniles, comparison of these values indicates that M. margaritifera appears to be more sensitive to $\mathrm{NaCl}$ than other freshwater mussel species, since lower toxicity thresholds would be expected in younger, especially recently excysted, juveniles.

\subsection{Toxicity Thresholds}

Little is known about the sensitivity of the FWPM to pollution threats. Many programs have been set up for the reinforcement of the FWPM population in Europe [9], but research on this organism's pollutant sensitivity is scarce. This could be partially explained by its endangered species status since M. margaritifera is protected by appendix III of the Bern Convention, by the European habitats Directive annexes II and V and is included in the red list of the International Union for Conservation of Nature as being critically endangered in Europe. This in turn leads to difficulty in using this organism for laboratory testing, a problem that is further compounded by the long-life span and complex life cycle of this species, which as a consequence, requires knowledge of potential threats affecting both the FWPM's different life stages as well as its host population $[2,4,15]$. However, several field studies have provided estimates of low water-quality thresholds in rivers where recruitment has been observed [30], and have allowed showing a positive correlation between increasing nitrate concentrations and adult mortality [23]. Moreover, a recent French study conducted laboratory experiments to study the effects of cadmium exposure on FWPM adults sampled from the Dronne river [39]. Organisms were exposed to 2 and $5 \mu \mathrm{g} \mathrm{Cd/L} \mathrm{for} 7$ days and ecotoxicological biomarkers such as gonad histological observations, metal bioaccumulation, metallothionein production, malondialdehyde concentrations and quantitative relative expression analysis of genes were assessed. The results of this study, which was the first to use various toxicological biomarkers to investigate the impact of cadmium exposure on M. margaritifera adults, provided new knowledge about the sensitivity of the freshwater pearl mussel, in particular highlighting the disruptive effect of this metal trace element on adult endocrine function. However, despite the fact that early life stages are considered to be the critical survival period for this species [14,15], to our knowledge, only one ecotoxicological study has hitherto been conducted on M. margaritifera juveniles [53]. This previous study, in which the effects of $\mathrm{pH}, \mathrm{Al}$ and iron (Fe) on 
the survival of early life stages of $M$. margaritifera were assessed at $17-18{ }^{\circ} \mathrm{C}$, reported relatively low effects of $\mathrm{Al}$ and Fe after $168 \mathrm{~h}$ exposure on the survival of newly transformed juveniles. Even at the highest concentrations tested ( $1 \mathrm{mg} \mathrm{Al} / \mathrm{L}$ and $2 \mathrm{mg} \mathrm{Fe} / \mathrm{L})$, survival rates were over $80 \%$. In our study, the $96 \mathrm{~h}$ median effective concentration (96 h EC50) for Al on 28-month-old juveniles was $>0.954 \mathrm{mg} / \mathrm{L}$. Those findings showed that newly transformed or older juveniles (by several months) are more tolerant to high concentrations of $\mathrm{Al}$ in a short-term exposure since, according to the FOREGS base data [54], mean measured concentrations of Al found in European stream waters is $75.5 \pm 180 \mu \mathrm{g} \mathrm{Al} / \mathrm{L}$. Similar results were obtained for As and Cd, since the $96 \mathrm{~h}$ EC50 determined in the present study was greater than $127 \mu \mathrm{g}$ As/L for 17 month old juveniles and from 110 to $147 \mu \mathrm{g} \mathrm{Cd} / \mathrm{L}$ for 16 to 22 month old juveniles. Moreover, EC10 for cadmium was $75 \mu \mathrm{g} / \mathrm{L}$, which underlies the high tolerance of juveniles to acute cadmium exposure. In the Dronne river, measured Cd concentrations in 2015 and 2018 were under the detection limit $(<0.61 \mu \mathrm{g} \mathrm{Cd} / \mathrm{L})$, whereas the maximum measured concentrations of $\mathrm{Al}$ and As were $120 \mu \mathrm{g} \mathrm{Al} / \mathrm{L}$ and $35 \mu \mathrm{g} \mathrm{As} / \mathrm{L}$, respectively (unpublished data). Since drinking-water threshold for As fixed by the World Health Organization (WHO) is $10 \mu \mathrm{g} \mathrm{As/L,} \mathrm{the} \mathrm{relatively} \mathrm{high}$ As concentration could be related to background levels in the studied site [55], perhaps leading to an adaptation of the mussel to such high environmental As concentrations. Moreover, the high tolerance of M. margaritifera juveniles aged from 16 to 22 months to high concentrations of $\mathrm{Al}, \mathrm{Cd}$ and As could be explained by the capacity of mussels to avoid contaminant exposure by temporarily closing their valves during laboratory testing $[16,32,56]$. It is relevant in this context that another study showed that toxicity thresholds were increased at least threefold when two-month-old Lampsilis siliquoidea juveniles were transferred to clean water without contaminant for $24 \mathrm{~h}$ after a $96 \mathrm{~h}$ toxicity tests to copper whereas for newly transformed juveniles, toxicity threshold was similar after the 24 h recovery time. Moreover, for ammonia exposure, EC50s were found to be similar for newly transformed and two-month-old juveniles of L. siliquoidea [16]. This finding led to the conclusion that depending on the pollutant studied, older juveniles (months) were avoiding pollutant exposure by closing their valves since survival was assessed by checking mussel foot movement. In the present study, juvenile FWPM viability was also evaluated by checking foot movement within a 5 min assessment period. Interestingly, most of the dead mussels remained open with their motionless foot projecting out of the valves. Since mussels might have reduced the filtration process that would be the main mediator for environmental pollutant intake, this potential capacity of avoiding toxicant exposure by FWMP juveniles could lead to an underestimation of actual contaminant toxicity. However, since the current study showed the high tolerance of FWPM juveniles to acute concentrations of metal trace elements $(\mathrm{Al}, \mathrm{As}$ and $\mathrm{Cd})$ and nutrients $\left(\mathrm{NO}_{3}{ }^{-}\right.$and $\left.\mathrm{PO}_{4}{ }^{3-}\right)$ in short-term exposure, further studies investigating the sublethal effects of pollutants in long-term exposures are now needed to complete our knowledge of survival responsiveness.

Water-quality degradation has been reported to be an important factor in imperiling FWPM populations, especially arising from the presence of nutrients involved in the eutrophication process $[1,28,57]$. An Irish field study reported estimates of median nutrient levels found in reproducing Margaritifera containing rivers [30], with values being $0.005 \mathrm{mg} \mathrm{PO}_{4}{ }^{3-} / \mathrm{L}$ for orthophosphates and $0.553 \mathrm{mg} \mathrm{NO}_{3}{ }^{-} / \mathrm{L}$ for nitrate. Another study through field observations on 13 Bavarian rivers (Germany) found that adult mortality was positively correlated with increasing water nitrate concentrations from 6.6 to $13.29 \mathrm{mg} \mathrm{NO}_{3}{ }^{-} / \mathrm{L}$, and that increased levels of phosphate, calcium and biological oxygen demand were correlated with decreased survival and the establishment of juvenile mussel populations [23]. In our study, the $96 \mathrm{~h}$ median effective concentrations for nitrate and ortho-phosphate on 13-month old juveniles were between 1000 and $1500 \mathrm{mg} \mathrm{NO}_{3}{ }^{-} / \mathrm{L}$ and $>5.01 \mathrm{mg} \mathrm{PO}_{4}{ }^{3-} / \mathrm{L}$, respectively. We also found that 13-month-old juveniles are tolerant to very high concentrations of $\mathrm{NO}_{3}{ }^{-}$and $\mathrm{PO}_{4}{ }^{3-}$ in short-term and single contaminant exposures at $16{ }^{\circ} \mathrm{C}$, which is in accordance with the high tolerance of other species of freshwater mussels to nitrate exposure. Indeed, previous acute toxicity tests conducted at $20^{\circ} \mathrm{C}$ on newly transformed juveniles of $U$. crassus and A. anatina established $96 \mathrm{~h}$ median lethal concentrations of 2233 and $1635 \mathrm{mg} \mathrm{NO}_{3}{ }^{-} / \mathrm{L}$, respectively [57]. Moreover, a recent study conducted 
acute toxicity tests to nitrate on different freshwater species including a freshwater mussel (L. siliquoidea) and allowed the assessment of nitrate EC50s ranging from $837 \mathrm{mg} \mathrm{NO}_{3}^{-} / \mathrm{L}$ to over $3912 \mathrm{mg} \mathrm{NO}_{3}^{-} / \mathrm{L}^{-}$ for larvae midge (Chironomus dilitus) and rainbow trout juveniles (Oncorhynchus mykiss), respectively, with nitrate $\mathrm{EC} 50$ of $2946 \mathrm{mg} \mathrm{NO}_{3}{ }^{-} / \mathrm{L}$ for the unionid mussel [58]. However, these threshold values are significantly higher than the nitrate concentrations reported in the natural environment. In fact, in the Dronne river, the maximum measured nitrate and ortho-phosphate concentrations were $9.4 \mathrm{mg} \mathrm{NO}_{3}^{-} / \mathrm{L}^{-}$ and $0.22 \mathrm{mg} \mathrm{PO}_{4}{ }^{3-} / \mathrm{L}$ according to the water information system of the "Adour-Garonne" web site. This therefore suggests that these nutrients are in concentrations in the Dronne river that are significantly lower than levels affecting M. margaritifera juvenile survival. Nevertheless, the little available data on nitrate toxicity in freshwater mussels makes it difficult to determine whether these nutrients at high levels have a direct effect on mussel populations or whether their impact is more indirect through habitat impairment [57]. Moreover, nitrates and phosphates might not be found to be toxic when studied separately in laboratory experimental conditions, but rather, their adverse effects may arise from a concomitant interaction with other environmental factors such as dissolved oxygen, $\mathrm{pH}$ and temperature $[27,59]$.

However, it is important to emphasize that our experiments were based on the assessment of juvenile viability, whereas at the same exposure concentrations, the physiology and metabolism of the mussels could still be impacted and sublethal effects might be occurring. Moreover, median effective concentration values from the current study were obtained from $96 \mathrm{~h}$ exposure testing. Further studies into long-term exposure are now needed in order to assess the full impact of environmentally relevant concentrations of contaminants, studied both independently and in combination, and in addition to other environmental factors such as temperature or dissolved oxygen. Such a multifactorial approach could allow investigation into the potential broader effects of climate change with increasing temperatures $[17,57]$.

\subsection{Age-Related Sensitivity}

Margaritifera margaritifera is a long-living species whose juvenile stage starts at the moment they drop off from the host fish gills, then lasts for 10 to 15 years until sexual maturity is reached [28]. Consequently, the juvenile's sensitivity to a particular contaminant may differ significantly according to age [60]. In the present study, a comparison of the sensitivity of 10- and 22-month-old juveniles in 48-h acute toxicity testing to sodium chloride and 16- and 22-month-old juveniles in $96 \mathrm{~h}$ acute exposures to cadmium were made. The results showed a slightly enhanced sensitivity for younger juveniles in both cases. Since the $96 \mathrm{~h}$ EC50s were greater than 110 and $112 \mu \mathrm{g} \mathrm{Cd} / \mathrm{L}$ in both cadmium experiments, a direct comparison of toxicity thresholds was not possible. However, the viability of 16-month old juveniles was adversely affected by $110 \mu \mathrm{g} \mathrm{Cd} / \mathrm{L}$, with a viability percentage of $80 \%$, whereas at the same concentration, the viability of 22-month old juveniles remained $100 \%$, thus indicative of a sensitivity related to age. Moreover, 10-month-old juveniles were found to be more sensitive to $\mathrm{NaCl}$ than older 22-month-old juveniles with EC50s of $0.96 \mathrm{~g} / \mathrm{L}$ and $1.5 \mathrm{~g} / \mathrm{L}$ for 10-month-old and 22-month-old juveniles, respectively. This is in accordance with the age-dependent sensitivity reported for other freshwater mussel species. For example, although two-month-old juveniles from the Unionidae family display a sensitivity to ammonia that is similar to that of newly transformed juveniles, the tolerance to copper is lower than in the younger animals [16]. Moreover, acute sensitivity to the toxic effects of lead, cadmium and zinc has been found to be higher in newly transformed Unionidae mussels than in glochidia, and also compared to older 2- to 6-month-old Unionidae juveniles [61]. Those findings, therefore, underline the importance of studying the most relevant life-stage and to take the age factor into account when comparing juvenile contaminant sensitivities between different studies.

\section{Conclusions}

The present study provides new data on the toxicant sensitivity of Margaritifera margaritifera juveniles in demonstrating that animals aged from 13 to 28 months were found to be tolerant to 
concentrations of $\mathrm{Al}, \mathrm{Cd}, \mathrm{As}, \mathrm{PO}_{4}{ }^{3-}, \mathrm{NO}_{3}{ }^{-}$and $\mathrm{NaCl}$, that are largely higher than those found in the Dronne river, under $96 \mathrm{~h}$ experimental exposure conditions. These findings suggest that nutrients and trace metals studied in this present study, are significantly lower in the Dronne river than levels of toxicant affecting FWPM juveniles. Moreover, the tolerance of FWPM juveniles appears to be dependent on age, with younger juveniles suggested as being more sensitive than older individuals, a finding that emphasizes the importance of studying early life stages of this species and notably freshly excysted juveniles. However, further studies on the sub-lethal effects (e.g., gene expression, mussel physiology and behavior etc.) of those contaminants are now needed since this could enable the detection of significant deleterious effects at lower contaminant concentrations and with long-term exposure [17,57]. Moreover, since single-contaminant exposure might not alone affect juvenile viability, studies on multiple-stress effects might be more relevant (e.g., chronic exposure to a mixture of nitrates and phosphate at different temperatures). Nevertheless, this study has improved our knowledge about this endangered species and has pointed to the ecological and ecotoxicological directions needed to develop future conservation strategies.

Supplementary Materials: The following are available online at http://www.mdpi.com/2076-3298/7/6/48/s1, Figure S1: Viability ( $\% \pm \mathrm{SD}$ ) of 10-month old M. margaritifera juveniles exposed to sodium chloride in 48-h acute toxicity test conducted at $16^{\circ} \mathrm{C}$; Table S1: Mean values $( \pm \mathrm{SD})$ measured at the beginning of the test, for water parameters ( $\mathrm{pH}$, conductivity, dissolved oxygen and temperature) in 48-h acute toxicity tests; Table S2: Mean measured values $( \pm \mathrm{SD})$ for $\mathrm{pH}$, temperature $\left({ }^{\circ} \mathrm{C}\right)$, conductivity $(\mu \mathrm{s} / \mathrm{cm})$ and dissolved oxygen $(\mathrm{mg} / \mathrm{L})$ at the beginning and at the end of each acute toxicity tests conducted in this study in Control, low, medium and high exposure conditions $(n=3)$; Table S3: Nominal concentrations, mean measured concentration values $\pm \operatorname{SD}(n=3)$ and mean percentage viability $\pm \operatorname{SD}(n=4)$ at the end of the test (based on juveniles immobility) for each acute toxicity tests.

Author Contributions: Conceptualization, T.B., M.B. and A.L.; methodology, T.B. and B.E.; formal analysis, T.B.; investigation, T.B.; resources, P.-Y.G. and M.-A.C.; writing-original draft preparation, T.B.; writing-review and editing, T.B., M.B., A.L., M.-A.C., B.E. and P.-Y.G.; visualization, T.B.; supervision, M.B. and A.L.; funding acquisition, M.B. All authors have read and agreed to the published version of the manuscript.

Funding: This research was funded by the LIFE programme (LIFE13 NAT/FR/000506).

Acknowledgments: This work was supported by the LIFE13 NAT/FR/000506 program, funded by the European Commission, "Agence de l'Eau Adour Garonne", New Aquitaine Region, the Dordogne Department, the French government and the "Initiative Biosphere Dordogne".

Conflicts of Interest: The authors declare no conflict of interest.

\section{References}

1. Strayer, D.L.; Downing, J.A.; Haag, W.R.; King, T.L.; Layzer, J.B.; Newton, T.J.; Nichols, S.J. Changing Perspectives on Pearly Mussels, North America's Most Imperiled Animals. Bioscience 2004, 54, 429. [CrossRef]

2. Bogan, A.E. Freshwater Bivalve Extinctions (Mollusca: Unionoida): A Search for Causes. Integr. Comp. Biol. 1993, 33, 599-609. [CrossRef]

3. Young, M.R.; Cosgrove, P.J.; Hastie, L.C. The Extent of, and Causes for, the Decline of a Highly Threatened Naiad: Margaritifera margaritifera. In Ecology and Evolution of the Freshwater Mussels Unionoida; Springer: Berlin/Heidelberg, Germany, 2001; pp. 337-357. [CrossRef]

4. Hastie, L.C.; Young, M.R. Freshwater Pearl Mussel (Margaritifera margaritifera) Glochidiosis in Wild and Farmed Salmonid Stocks in Scotland. Hydrobiologia 2001, 445, 109-119. [CrossRef]

5. Gumpinger, C.; Hauer, C.; Scheder, C. The Current Status and Future Challenges for the Preservation and Conservation of Freshwater Pearl Mussel Habitats. Limnologica 2015, 50, 1-3. [CrossRef]

6. Hauer, C. Review of Hydro-Morphological Management Criteria on a River Basin Scale for Preservation and Restoration of Freshwater Pearl Mussel Habitats. Limnologica 2015, 50, 40-53. [CrossRef]

7. Scheder, C.; Lerchegger, B.; Flödl, P.; Csar, D.; Gumpinger, C.; Hauer, C. River Bed Stability versus Clogged Interstitial: Depth-Dependent Accumulation of Substances in Freshwater Pearl Mussel (Margaritifera margaritifera L.) Habitats in Austrian Streams as a Function of Hydromorphological Parameters. Limnologica 2015, 50, 29-39. [CrossRef] 
8. Lopes-Lima, M.; Sousa, R.; Geist, J.; Aldridge, D.C.; Araujo, R.; Bergengren, J.; Bespalaya, Y.; Bódis, E.; Burlakova, L.; Van Damme, D.; et al. Conservation Status of Freshwater Mussels in Europe: State of the Art and Future Challenges. Biol. Rev. 2017, 92, 572-607. [CrossRef]

9. Gum, B.; Lange, M.; Geist, J. A Critical Reflection on the Success of Rearing and Culturing Juvenile Freshwater Mussels with a Focus on the Endangered Freshwater Pearl Mussel (Margaritifera margaritifera L.). Aquat. Conserv. Mar. Freshw. Ecosyst. 2011, 21, 743-751. [CrossRef]

10. Barnhart, M.C.; Haag, W.R.; Roston, W.N. Adaptations to Host Infection and Larval Parasitism in Unionoida. J. N. Am. Benthol. Soc. 2008, 27, 370-394. [CrossRef]

11. Haag, W.R. North American Freshwater Mussels: Natural History, Ecology, and Conservation; Southern Research Station: Asheville, NC, USA, 2012; pp. 1-521. [CrossRef]

12. Geist, J.; Auerswald, K. Physicochemical Stream Bed Characteristics and Recruitment of the Freshwater Pearl Mussel (Margaritifera margaritifera). Freshw. Biol. 2007, 52, 2299-2316. [CrossRef]

13. Geist, J. Strategies for the Conservation of Endangered Freshwater Pearl Mussels (Margaritifera margaritifera L.): A Synthesis of Conservation Genetics and Ecology. Hydrobiologia 2010, 644, 69-88. [CrossRef]

14. Naimo, T.J. A Review of the Effects of Heavy Metals on Freshwater Mussels. Ecotoxicology 1995, 4, 341-362. [CrossRef]

15. Österling, M.E.; Greenberg, L.A.; Arvidsson, B.L. Relationship of Biotic and Abiotic Factors to Recruitment Patterns in Margaritifera margaritifera. Biol. Conserv. 2008, 141, 1365-1370. [CrossRef]

16. Wang, N.; Ingersoll, C.G.; Hardesty, D.K.; Ivey, C.D.; Kunz, J.L.; May, T.W.; Dwyer, F.J.; Roberts, A.D.; Augspurger, T.; Kane, C.M.; et al. Acute Toxicity of Copper, Ammonia, and Chlorine to Glochidia and Juveniles of Freshwater Mussels (Unionidae). Environ. Toxicol. Chem. 2007, 26, 2036-2047. [CrossRef] [PubMed]

17. Ferreira-Rodríguez, N.; Akiyama, Y.B.; Aksenova, O.V.; Araujo, R.; Christopher Barnhart, M.; Bespalaya, Y.V.; Bogan, A.E.; Bolotov, I.N.; Budha, P.B.; Clavijo, C.; et al. Research Priorities for Freshwater Mussel Conservation Assessment. Biol. Conserv. 2019, 231, 77-87. [CrossRef]

18. Gramstad, J. Finding the Way to Food, Patch Quality Evaluation Performed by Young of the Year Freshwater Pearl Mussels (Margaritifera margaritifera). Master's Thesis, University of Bergen, Bergen, Norway, 2014.

19. Lavictoire, L.; Moorkens, E.; Ramsey, A.D.; Sinclair, W.; Sweeting, R.A. Effects of Substrate Size and Cleaning Regime on Growth and Survival of Captive-Bred Juvenile Freshwater Pearl Mussels, Margaritifera margaritifera (Linnaeus, 1758). Hydrobiologia 2016, 766, 89-102. [CrossRef]

20. Schartum, E.; Mortensen, S.; Pittman, K.; Jakobsen, P.J. From Pedal to Filter Feeding: Ctenidial Organogenesis and Implications for Feeding in the Postlarval Freshwater Pearl Mussel Margaritifera margaritifera (Linnaeus, 1758). J. Molluscan Stud. 2017, 83, 36-42. [CrossRef]

21. Araujo, R.; Campos, M.; Feo, C.; Varela, C.; Soler, J.; Ondina, P. Who Wins in the Weaning Process? Juvenile Feeding Morphology of Two Freshwater Mussel Species. J. Morphol. 2018, 279, 4-16. [CrossRef]

22. Lavictoire, L.; Ramsey, A.D.; Moorkens, E.A.; Souch, G.; Barnhart, M.C. Ontogeny of Juvenile Freshwater Pearl Mussels, Margaritifera margaritifera (Bivalvia: Margaritiferidae). PLoS ONE 2018, 13. [CrossRef]

23. Bauer, G. Threats to the Freshwater Pearl Mussel Margaritifera margaritifera L. in Central Europe. Biol. Conserv. 1988, 45, 239-253. [CrossRef]

24. Augspurger, T.; Eller, A.E.; Lack, M.C.; Cope, W.G.; Dwyer, F.J. Water Quality Guidance for Protection of Freshwater Mussels (Unionidae) from Ammonia Exposure. Environ. Toxicol. Chem. 2003, 22, 2569-2575. [CrossRef] [PubMed]

25. Soucek, D.J.; Dickinson, A. Acute Toxicity of Nitrate and Nitrite to Sensitive Freshwater Insects, Mollusks, and a Crustacean. Arch. Environ. Contam. Toxicol. 2012, 62, 233-242. [CrossRef]

26. Camargo, J.A.; Alonso, Á. Ecological and Toxicological Effects of Inorganic Nitrogen Pollution in Aquatic Ecosystems: A Global Assessment. Environ. Int. 2006, 32, 831-849. [CrossRef] [PubMed]

27. Camargo, J.A.; Alonso, A.; Salamanca, A. Nitrate Toxicity to Aquatic Animals: A Review with New Data for Freshwater Invertebrates. Chemosphere 2005, 58, 1255-1267. [CrossRef] [PubMed]

28. Skinner, A.; Young, M.; Hastie, L. Ecology of the Freshwater Pearl Mussel Margaritifera margaritifera; Conserving Natura 2000 Rivers Ecology Series; English Nature: Peterborough, UK, 2003.

29. Moorkens, E. Conservation Management of the Freshwater Pearl Mussel Margaritifera margaritifera. Part 2: Water Quality Requirements. In Irish Wildlife Manuals; Dúchas, The Heritage Service: Dublin, Ireland, 2000.

30. Moorkens, E. Irish Non-Marine Molluscs-an Evaluation of Species Treat Status. Bull. Ir. Biogeographical Soc. 2006, 30, 348-371. 
31. Genin, B.; Chauvin, C.; Ménard, F. Cours d'eau et Indices Biologiques: Pollutions, Méthodes, IBGN; ENESAD-CNERTA: Dijon, France, 1997.

32. Cope, W.G.; Bringolf, R.B.; Buchwalter, D.B.; Newton, T.J.; Ingersoll, C.G.; Wang, N.; Augspurger, T.; Dwyer, F.J.; Barnhart, M.C.; Neves, R.J.; et al. Differential Exposure, Duration, and Sensitivity of Unionoidean Bivalve Life Stages to Environmental Contaminants. J. N. Am. Benthol. Soc. 2008, 27, 451-462. [CrossRef]

33. Jorge, M.B.; Loro, V.L.; Bianchini, A.; Wood, C.M.; Gillis, P.L. Mortality, Bioaccumulation and Physiological Responses in Juvenile Freshwater Mussels (Lampsilis siliquoidea) Chronically Exposed to Copper. Aquat. Toxicol. 2013, 126, 137-147. [CrossRef]

34. Guidi, P.; Frenzilli, G.; Benedetti, M.; Bernardeschi, M.; Falleni, A.; Fattorini, D.; Regoli, F.; Scarcelli, V.; Nigro, M. Antioxidant, Genotoxic and Lysosomal Biomarkers in the Freshwater Bivalve (Unio pictorum) Transplanted in a Metal Polluted River Basin. Aquat. Toxicol. 2010, 100, 75-83. [CrossRef]

35. Hemelraad, J.; Holwerda, D.A.; Herwig, H.J.; Zandee, D.I. Effects of Cadmium in Freshwater Clams. III. Interaction with Energy Metabolism in Anodonta Cygnea. Arch. Environ. Contam. Toxicol. 1990, 19, 699-703. [CrossRef]

36. Keller, A.E.; Zam, S.G. The Acute Toxicity of Selected Metals to the Freshwater Mussel, Anodonta Imbecilis. Environ. Toxicol. Chem. 1991, 10, 539. [CrossRef]

37. Legeay, A.; Achard-Joris, M.; Baudrimont, M.; Massabuau, J.C.; Bourdineaud, J.P. Impact of Cadmium Contamination and Oxygenation Levels on Biochemical Responses in the Asiatic Clam Corbicula Fluminea. Aquat. Toxicol. 2005, 74, 242-253. [CrossRef] [PubMed]

38. Giacomin, M.; Gillis, P.L.; Bianchini, A.; Wood, C.M. Interactive Effects of Copper and Dissolved Organic Matter on Sodium Uptake, Copper Bioaccumulation, and Oxidative Stress in Juvenile Freshwater Mussels (Lampsilis siliquoidea). Aquat. Toxicol. 2013, 144-145, 105-115. [CrossRef]

39. Baudrimont, M.; Gonzalez, P.; Mesmer-Dudons, N.; Legeay, A. Sensitivity to Cadmium of the Endangered Freshwater Pearl Mussel Margaritifera margaritifera from the Dronne River (France): Experimental Exposure. Environ. Sci. Pollut. Res. 2020, 27, 3715-3725. [CrossRef] [PubMed]

40. Bertucci, A.; Pierron, F.; Thébault, J.; Klopp, C.; Bellec, J.; Gonzalez, P.; Baudrimont, M. Transcriptomic Responses of the Endangered Freshwater Mussel Margaritifera margaritifera to Trace Metal Contamination in the Dronne River, France. Environ. Sci. Pollut. Res. 2017, 24, 27145-27159. [CrossRef] [PubMed]

41. Cochet, G.; Gouilloux, N. La Moule Perlière et Les Nayades de France: Histoire d'une Sauvegarde; Histoire d'une Sauvegarde; Catiche Productions: Nohanent, France, 2004.

42. ASTM E2455. American Society for Testing and Materials, Standard Guide for Conducting Laboratory Toxicity Tests with Freshwater Mussels E 2455-06; ASTM International: West Conshohocken, PA, USA, 2006. [CrossRef]

43. Valenti, T.W. Approaches for Assessing Toxicity of Selected Contaminants to Freshwater Mussels (Bivalvia: Unionidae). Ph.D. Thesis, Virginia Polytechnic Institute and State University, Blacksburg, VA, USA, 2004.

44. US Environmental Protection Agency. Methods for Measuring the Acute Toxicity of Effluents and Receiving Waters to Freshwater and Marine Organisms, 5th ed.; US Environmental Protection Agency: Washington, DC, USA, 2002; Volume 232.

45. Ritz, C. Toward a Unified Approach to Dose-Response Modeling in Ecotoxicology. Environ. Toxicol. Chem. 2010, 29, 220-229. [CrossRef] [PubMed]

46. Wang, N.; Consbrock, R.A.; Ingersoll, C.G.; Barnhart, M.C. Evaluation of Influence of Sediment on the Sensitivity of a Unionid Mussel (Lampsilis siliquoidea) to Ammonia in 28-Day Water Exposures. Environ. Toxicol. Chem. 2011, 30, 2270-2276. [CrossRef] [PubMed]

47. Wang, N.; Kunz, J.L.; Dorman, R.A.; Ingersoll, C.G.; Steevens, J.A.; Hammer, E.J.; Bauer, C.R. Evaluation of Chronic Toxicity of Sodium Chloride or Potassium Chloride to a Unionid Mussel (Lampsilis siliquoidea) in Water Exposures Using Standard and Refined Toxicity Testing Methods. Environ. Toxicol. Chem. 2018, 37, 3050-3062. [CrossRef]

48. Wang, N.; Ivey, C.D.; Ingersoll, C.G.; Brumbaugh, W.G.; Alvarez, D.; Hammer, E.J.; Bauer, C.R.; Augspurger, T.; Raimondo, S.; Barnhart, M.C. Acute Sensitivity of a Broad Range of Freshwater Mussels to Chemicals with Different Modes of Toxic Action. Environ. Toxicol. Chem. 2017, 36, 786-796. [CrossRef]

49. Wang, N.; Ivey, C.D.; Dorman, R.A.; Ingersoll, C.G.; Steevens, J.; Hammer, E.J.; Bauer, C.R.; Mount, D.R. Acute Toxicity of Sodium Chloride and Potassium Chloride to a Unionid Mussel (Lampsilis siliquoidea) in Water Exposures. Environ. Toxicol. Chem. 2018, 37, 3041-3049. [CrossRef] 
50. Elphick, J.R.F.; Bergh, K.D.; Bailey, H.C. Chronic Toxicity of Chloride to Freshwater Species: Effects of Hardness and Implications for Water Quality Guidelines. Environ. Toxicol. Chem. 2011, 30, 239-246. [CrossRef]

51. Mount, D.R.; Erickson, R.J.; Highland, T.L.; Hockett, J.R.; Hoff, D.J.; Jenson, C.T.; Norberg-King, T.J.; Peterson, K.N.; Polaske, Z.M.; Wisniewski, S. The Acute Toxicity of Major Ion Salts to Ceriodaphnia Dubia: I. Influence of Background Water Chemistry. Environ. Toxicol. Chem. 2016, 35, 3039-3057. [CrossRef] [PubMed]

52. Soucek, D.J.; Linton, T.K.; Tarr, C.D.; Dickinson, A.; Wickramanayake, N.; Delos, C.G.; Cruz, L.A. Influence of Water Hardness and Sulfate on the Acute Toxicity of Chloride to Sensitive Freshwater Invertebrates. Environ. Toxicol. Chem. 2011, 30, 930-938. [CrossRef]

53. Taskinen, J.; Berg, P.; Saarinen-Valta, M.; Välilä, S.; Mäenpää, E.; Myllynen, K.; Pakkala, J. Effect of PH, Iron and Aluminum on Survival of Early Life History Stages of the Endangered Freshwater Pearl Mussel, Margaritifera margaritifera. Toxicol. Environ. Chem. 2011, 93, 1764-1777. [CrossRef]

54. Salminen, R.; Batista, M.J.; Bidovec, M.; Demetriades, A.; De Vivo, B.; De Vos, W.; Duris, M.; Gilucis, A.; Gregorauskiene, V.; Halamić, J.; et al. Forum of European Geological Surveys (FOREGS)-Statistical Data of Analytical Results. Available online: http://weppi.gtk.fi/publ/foregsatlas/article.php?id=15 (accessed on 25 March 2020).

55. Mauroux, B.; Wyns, R.; Castagnac, C.; Prognon, C.; Zammit, C.; Martelet, G.; Lions, J.; Touchard, F.; Karnay, G. SILURES Limousin, Module 1, SILURES «Base de Données» Recueil des Données, Interprétations et Bilans-Rapport Final; BRGM: Limoges, France, 2009.

56. Farris, J.L.; Van Hassel, J.H.; Society, S. A Review of the Use of Unionid Mussels as Biological Indicators of Ecosystem Health. In Freshwater Bivalve Ecotoxicology; CRC Press: Pensacola, FL, USA, 2007.

57. Douda, K. Effects of Nitrate Nitrogen Pollution on Central European Unionid Bivalves Revealed by Distributional Data and Acute Toxicity Testing. Aquat. Conserv. Mar. Freshw. Ecosyst. 2010, 20, 189-197. [CrossRef]

58. Wang, N.; Dorman, R.A.; Ivey, C.D.; Soucek, D.J.; Dickinson, A.; Kunz, B.K.; Steevens, J.A.; Hammer, E.J.; Bauer, C.R. Acute and Chronic Toxicity of Sodium Nitrate and Sodium Sulfate to Several Freshwater Organisms in Water-Only Exposures. Environ. Toxicol. Chem. 2020, 39, 1071-1085. [CrossRef] [PubMed]

59. Baker, J.A.; Gilron, G.; Chalmers, B.A.; Elphick, J.R. Evaluation of the Effect of Water Type on the Toxicity of Nitrate to Aquatic Organisms. Chemosphere 2017, 168, 435-440. [CrossRef]

60. Jacobson, P.J.; Cherry, D.S.; Farris, J.L.; Neves, R.J. Juvenile Freshwater Mussel (Bivalvia: Unionidae) Responses to Acute Toxicity Testing with Copper. Environ. Toxicol. Chem. 1993, 12, 879-883. [CrossRef]

61. Wang, N.; Ingersoll, C.G.; Ivey, C.D.; Hardesty, D.K.; May, T.W.; Augspurger, T.; Roberts, A.D.; Van Genderen, E.; Barnhart, M.C. Sensitivity of Early Life Stages of Freshwater Mussels (Unionidae) to Acute and Chronic Toxicity of Lead, Cadmium, and Zinc in Water. Environ. Toxicol. Chem. 2010, 29, 2053-2063. [CrossRef]

(C) 2020 by the authors. Licensee MDPI, Basel, Switzerland. This article is an open access article distributed under the terms and conditions of the Creative Commons Attribution (CC BY) license (http://creativecommons.org/licenses/by/4.0/). 